\title{
Neurotoxic Effects of Ketamine and Different Doses of Ropivacaine Administered Intrathecally in Rabbits
}

\author{
Tavşanlarda İntratekal Uygulanan \\ Ketamin ve Farklı Dozlarda \\ Ropivakainin Nörotoksik Etkileri
}

\section{Gülbin SEZEN, ${ }^{a}$ \\ Yavuz DEMIRARAN, ${ }^{a}$ \\ Aysel GÜVEN ${ }^{b}$ \\ Handan ANKARALI, \\ Özdemir SEVINÇ, ${ }^{\circ}$ \\ İbrahim KARAGÖZ ${ }^{\mathrm{a}}$}

Departments of

${ }^{a}$ Anesthesiology and Reanimation,

'Biostatistics and Medical Informatics,

Düzce University of Medicine,

Düzce

Departments of

'Histology and Embriology,

${ }^{d A n a t o m y, ~}$

Çanakkale Onsekiz Mart University

Faculty of Medicine, Çanakkale

Geliş Tarihi/Received: 20.11.2012

Kabul Tarihi/Accepted: 11.06.2013

Yazışma Adresi/Correspondence: Gülbin SEZEN

Düzce University Faculty of Medicine, Department of

Anesthesiology and Reanimation,

Düzce,

TÜRKIYE/TURKEY

gysezen@hotmail.com

\begin{abstract}
Objective: Although a variety of anesthetic medicines are used intrathecally, experimental neurotoxic studies on these drugs are not sufficient. In our study, we used immunocytochemical examination to assess the neurotoxic potential of ketamine and different doses of ropivacaine administered intrathecally. Material and Methods: Thirty rabbits were divided into five groups which were inserted spinal catheters under anesthesia. Each group received in a volume of $0.3 \mathrm{ml}$, as follows: the $\mathrm{R} 0.2$ group received $0.2 \%$ ropivacaine, the $\mathrm{R} 0.75$ group received $0.75 \%$ ropivacaine, the $\mathrm{R} 1$ group received $1.0 \%$ ropivacaine, the $\mathrm{K}$ group received preservative-free $\mathrm{S}(+)$ ketamine and the $\mathrm{C}$ group received $0.9 \% \mathrm{NaCl}$. The onset and duration of action were recorded by using Motor Dysfunction Index (MDI). Rabbits were observed for five days and then euthanasized. After catheters were removed, brains and spinal tissue samples were evaluated by light microscopy and immunocytochemical examination. Results: The longest onset of action was observed in the K group. Among the ropivacaine groups, the onset of action diminished and the duration of action extended with an increase in dose significantly. There was axonal degeneration in the R1 group, but this finding not reach significance. In the ketamine group, significant neuronal degeneration and reduction in number of neurons in the brain sections were observed. In the $1 \%$ ropivacaine group, a relative increase in neurofilament intensity was detected using immunocytochemical assessments in the medulla spinalis and brain sections. Conclusion: The intrathecal applications of $1 \%$ ropivacaine and ketamine can induce neurotoxic damage, despite a lack of observed functional neurologic deficits.
\end{abstract}

Key Words: Ropivacaine; ketamine; injections, spinal

ÖZET Amaç: İntratekal olarak uygulanan anestezik ilaçların çeşitliliğine karşın, bu ilaçların deneysel nörotoksik çalışmaları yeterli değildir. Çalışmamızda, intratekal olarak verilen ketamin ve farklı dozlardaki ropivakainin nörotoksik potansiyelini immunohistokimyasal olarak değerlendirmeyi amaçladık. Gereç ve Yöntemler: Anestetize edilerek spinal kateter yerleştirilmiş 30 tavşan 5 gruba ayrild. Grup R0.2'de ropivakain $\% 0,2$, grup R0.75'de ropivakain $\% 0,75$, grup R1'de ropivakain $\% 1,0$, grup K'de preservative-free S (+) ketamin ve grup C'de $\% 0,9 \mathrm{NaCl} 0,3 \mathrm{ml}$ volümde spinal kateterden uygulandı. Etki başlangıç zamanı ve etki süreleri Motor Dysfunction Index (MDI) kullanılarak kaydedildi. Tavşanlar 5 gün gözlendikten sonra ötenazi uygulandı. Kateterler çıkarllarak beyin ve spinal doku örnekleri ışı mikroskopisi ve immunohistokimyasal metodla değerlendirildi. Bulgular: En uzun etki başlangıcı grup K'de gözlemlendi. Ropivakain grupları içinde doz artışı ile birlikte etki başlangıç süreleri kısalarak, etki süreleri uzamıș olarak tespit edildi. Grup R1'de aksonal degenerasyon gözlenmesine karşın istatistiksel anlamlılık bulunmadı, ketamin grubunda ise beyin kesitlerinde istatistiksel anlamlı olarak nöronal degenerasyon ve nöron sayısında azalma gözlendi. İmmunohistokimyasal değerlendirmede, medulla spinalis ve beyin kesitlerinde nörofilament yoğunluğunun, grup R1'de göreceli olarak artmış olduğu görüldü. Sonuç: İntratekal uygulanan ropivakain \%1 ve ketamin, fonksiyonel nörolojik hasar gözlenmeksizin nörotoksik hasarlanmaya sebep olabilir.

Anahtar Kelimeler: Ropivakain; ketamin; enjeksiyonlar, spinal

Turkiye Klinikleri J Med Sci 2013;33(4):1103-1111 doi: 10.5336/medsci.2012-3280

Copyright (C) 2013 by Türkiye Klinikleri 
I n order to achieve a systemic neuroaxial block, it is most desirable to use local anesthetics that have a long duration of action without local side effects. Ropivacaine, an aminoamide local anesthetic, is thought to be a reasonable alternative to bupivacaine because it is less cardiotoxic. ${ }^{1}$ Ropivacaine has the least affect on motor nerve conduction when intrathecally administered. ${ }^{2}$ The anesthetic agent, ketamine, is a phencyclidine derivative that has been used since the $1960 \mathrm{~s}^{3}{ }^{3}$ The local anesthetic effect of ketamine is due to the non-competetive antagonism of the opioid and the $\mathrm{N}$-methyl D-aspartate receptors. ${ }^{4}$ The usefulness of intrathecal ketamine in human and animal studies has been reported with differing results..$^{5-8}$

Although a variety of anesthetic medicines are used intrathecally on a daily basis, experimental neurotoxic studies on these drugs are not sufficient, and contradictory results have been reported. ${ }^{9-12}$ In order to increase the safety of clinical practices, there is a need for more experimental studies evaluating the neurotoxic effects of anesthetics, without the need for clinical feedback.

Neurofilaments (NF) are thought to serve primarily as structural components in the neuron, but they also play a fundamental role in axonal transport. NF and tubulin are cellular proteins that are of vital importance in maintaining the structural integrity and function of the neuron. ${ }^{13}$ Axonal NF accumulation, rather than perikaryal accumulation, is thought to be toxic for neurons, provoking axonal degeneration. ${ }^{14}$

In this study, we used immunocytochemical methods to detect NF changes, histochemical analysis to assess neuron health, and clinical evaluation to assess the functional neurotoxic potential of ropivacaine and ketamine in intrathecally injected rabbits. In addition, we tested the use and presentation of ropivacaine in variable concentrations.

\section{MATERIAL AND METHODS}

This study was approved by the Duzce University, School of Medicine Ethics Committee on Animal Experiments.

\section{EXPERIMENTAL DESIGN}

Animal rights are protected in this study, 30 female albinos New Zealand rabbits weighing $2.5 \pm 0.5$ $\mathrm{kg}$ received spinal anesthesia using the procedures suggested by Langerman. ${ }^{15}$ Briefly, each rabbit, placed in prone position, was administered ketamine $25 \mathrm{mg} / \mathrm{kg}$ and xylazine $\mathrm{HCl} 5 \mathrm{mg} / \mathrm{kg}$ intramuscularly (im). Under sterile conditions, a 24 G spinal catheter (Spinocath, Braun, Germany) was inserted within the L6-L7 or L7-S1 vertebrae, corresponding to the iliac spine. At the lumbosacral region, $27 \mathrm{G}$ Quincke needle was inserted through the subarachnoid area. Cerebrospinal fluid was aspirated for verifying insertion of spinal catheter into the subarachnoid area. Additionally, the location of the spinal catheter was radiologically confirmed.

To determine possible neurologic defects, the motor functions of the rabbits were observed for $24 \mathrm{~h}$. Animals were randomly divided into five groups using a random number table. Intrathecal injections were administered at the proximal side of the spinal catheter at the back of the neck. Each group received different doses or types of anesthesia administered in a volume of $0.3 \mathrm{ml}$, as follows: the $R_{0.2}$ group received $0.2 \%$ ropivacaine (Naropin, Astra Zeneca Comp. Canada), the $\mathrm{R}_{0.75}$ group received $0.75 \%$ ropivacaine, the $R_{1}$ group received $1.0 \%$ ropivacaine, the $\mathrm{K}$ group received preservative-free $\mathrm{S}(+)$ ketamine (Ketamine $10 \mathrm{mg} / \mathrm{ml}$, Curamed Pharma $\mathrm{GmbH}$, Germany) and the $\mathrm{C}$ group received $0.9 \% \mathrm{NaCl}$ (control group). After the injections, $0.1 \mathrm{ml} 0.9 \% \mathrm{NaCl}$ was administered in all groups for the dead space of the catheter.

The study groups are summarized as follows:

$0.2 \%$ Ropivacaine $0.3 \mathrm{ml}(0.6 \mathrm{mg})$, in group $R_{0.2}$

$0.75 \%$ Ropivacaine $0.3 \mathrm{ml}(2.25 \mathrm{mg})$, in group $\mathrm{R}_{0.75}$

$1.0 \%$ Ropivacaine $0.3 \mathrm{ml}$ ( $3 \mathrm{mg}$ ), in group $\mathrm{R}_{1}$ $5.0 \% \mathrm{~S}(+)$ ketamin $0.3 \mathrm{ml}(15 \mathrm{mg})$, in group $\mathrm{K}$ $0.9 \% \mathrm{NaCl} 0.3 \mathrm{ml}$, in group C

The onset time and duration of action were recorded during the post-injection period. In order to determine the onset time and duration of action, motor functions were assessed using the Motor 
Dysfunction Index (MDI) for periods of one minute until the maximum activity was observed. Thereafter, motor functions were observed for 10 minute periods (Table 1). ${ }^{9}$

Irritation signals as well as defecation and urination changes of the rabbits were observed and recorded for five days. Rabbits were then euthanasized by intracardiac anesthetic overdose (Pentothal $100 \mathrm{mg} / \mathrm{kg}$ ). After catheters were removed, the brains were extracted by cranial dissection, and spinal sections were prepared from two locations flanking the injection site. Histopathological analysis was performed blinded.

According to CONSORT guidelines, recruitment, enrollment, and retention of subjects are summarized in Figure 1.

\section{EXAMINATIONS BY LIGHT MICROSCOPY}

All spinal tissue specimens were obtained from the same region of the medulla spinalis. All brain tissu-
TABLE 1: Motor dysfunction index (MDI).

\begin{tabular}{|cl|}
\hline 0 & Normal motor function \\
\hline 1 & Dyscoordination during walk \\
\hline 2 & Inability to walk, but sufficient motor function to \\
& maintain a sitting position \\
\hline 3 & Inability to sit, but movement of the hindlegs \\
\hline 4 & Total paralysis \\
\hline
\end{tabular}

e specimens were divided into six equal-thickness coronal sections, collected in order from the frontal lobe to the occipital lobe. The specimens were fixed in $10 \%$ buffered formalin, embedded in paraffin, and cut into $5-\mu \mathrm{m}$-thick series sections. The sections were stained with hematoxylin-eosin and examined under a photomicroscope (Axioskop 40 Mikroskop Zeiss, AxioCam ICc3 Zeiss).

Using a light microscope to perform histopathologic examinations, tissues were evaluated for the presence or absence of axonal degeneration, de-

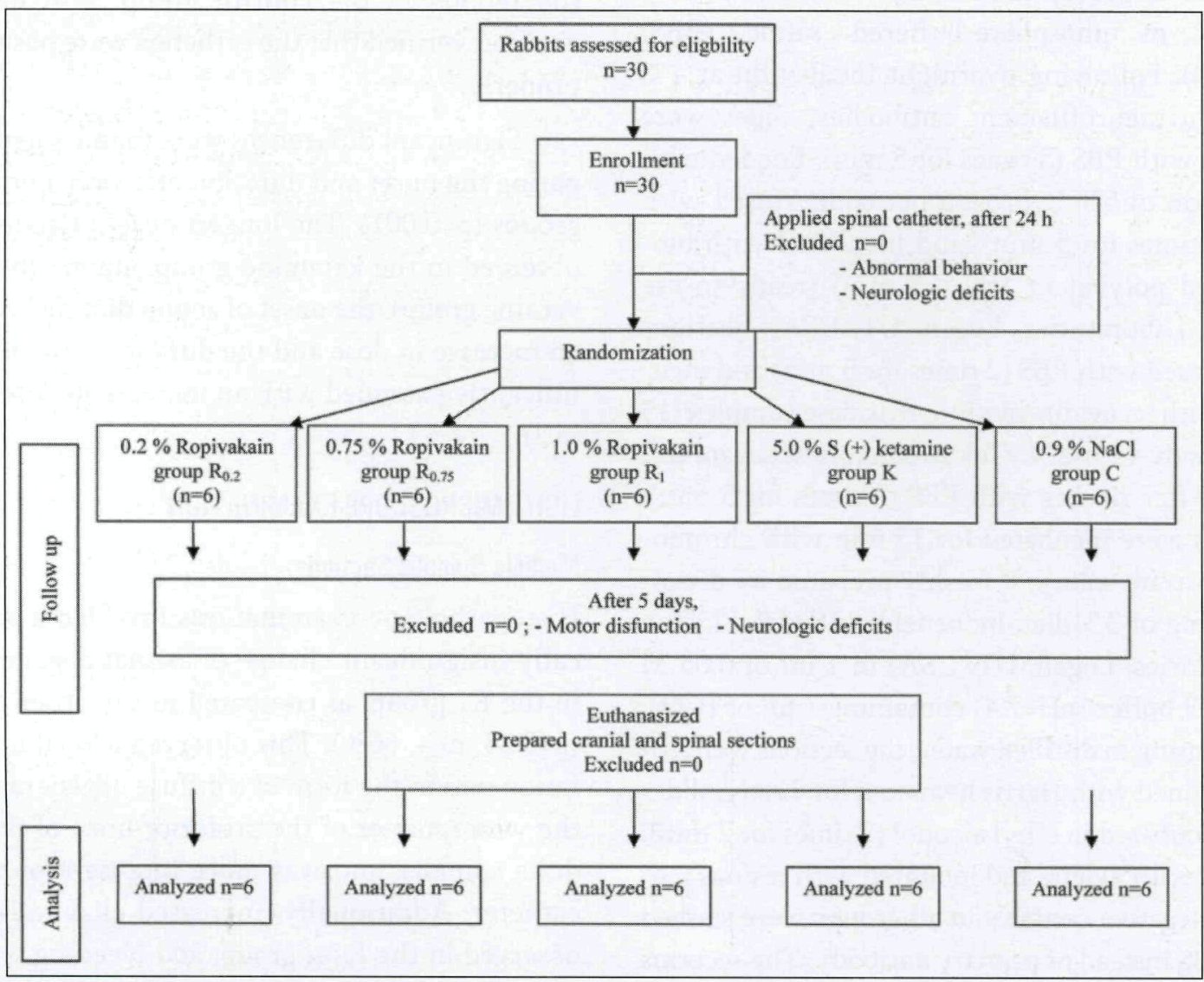

FIGURE 1: CONSORT flowchart summarizing enrollment and retention in the study protocol. 
generation in neurons, thinning of the ventricular wall surrounding the ependymal cells, an increase in glial cells and evidence of hemorrhage. In addition, tissue specimens from the dental gyrus and hippocampal CA1, CA2, CA3 regions (histological divisions of the hippocampus) were evaluated for the presence or absence of irregularities in neuronal integrity or a reduction in neuron number.

\section{IMMUNOHISTOCHEMICAL EXAMINATION}

All tissue samples (medulla spinalis, hippocampus, cerebral cortex and white matter) were fixed in 10\% buffered formalin, embedded in paraffin blocks, cut into $5-\mu \mathrm{m}$-thick sections and mounted onto poly-1lysine-coated microscope slides (Surgipath, Richmond USA). After deparaffinization of the sections, indirect immunohistochemical staining was applied, using the streptavidin-biotin-peroxidase method for neurofilament (NF) immunoreactivity (200 kDa and $68 \mathrm{kDa}$ ) with Ab-1 (ready-to-use Ab, Lab Vision, UK). Briefly, sections were treated with $3 \%$ hydrogen peroxide and methanol for 30 min to block endogenous peroxidase activity, and subsequently washed in phosphate-buffered saline (PBS) $(\mathrm{pH}=7.4)$. Following overnight incubation at $4^{\circ} \mathrm{C}$ with anti-neurofilament antibodies, slides were washed with PBS (3 times for $5 \mathrm{~min}$ ), flooded with a solution of $5 \%$ hydrogen peroxide, rinsed with PBS (2 times for $5 \mathrm{~min}$ ), and incubated with biotinylated polyvalent IgG (15 min) (ready-to-use SkyTek Laboratories, Logan, UT, USA). Sections were rinsed with PBS (2 times for $5 \mathrm{~min}$ ) and incubated with an avidin-biotin-peroxidase complex (15 min) (ready-to-use SkyTek Laboratories, Logan, UT, USA). After rinsing with PBS (2 times for $5 \mathrm{~min}$ ), sections were incubated for 15 min with chromogen substrate solution, freshly prepared by dissolving $1 \mathrm{mg}$ of 3,3-diaminobenzidine (DAB, SkyTek Laboratories, Logan, UT, USA) in $1 \mathrm{ml}$ of $0.05 \mathrm{M}$ Tris- $\mathrm{HCl}$ buffer $(\mathrm{pH}=7.4)$ containing $1 \mu \mathrm{L}$ of $\mathrm{H}_{2} \mathrm{O}_{2}$. After rinsing in distilled water, the sections were counterstained with Harris hematoxylin. Lastly, slides were incubated in ethyl alcohol (2 times for $2 \mathrm{~min}$ ), cleaned with xylene and mounted with resious medium. Negative controls in all groups were stained with PBS instead of primary antibody. The sections were lightly counterstained with hematoxylin.
The intensity of neurofilament-staining in sections from both the medulla spinalis and the brain were scored as absent ( 0 ), weak (1), moderate (2), strong (3) and very strong (4) (immunohistochemical scoring system).

\section{STATISTICAL ANALYSIS}

The Kruskal-Wallis test was used to analyze the differences in the effect of starting time of the anesthesia and duration of action among the groups. In addition, Dunn test followed by Kruskall-Wallis was used for detection significant difference. The likelihood ratio Chi square test was used to analyze the frequencies of the observed histopathologic changes among the groups. The SPSS (13.0) and NCSS (vers. 2007) programs were used in these analyses, and $\mathrm{p}<0.05$ was accepted as significant.

\section{RESULTS}

No neurologic deficits were observed in any of the anesthetized subjects during the 5 days observation period, and no motor dysfunction was observed in the rabbits in the control group. Post-mortem analyses verified that the catheters were positioned properly.

Significant differences were found when comparing the onset and duration of action among the groups ( $\mathrm{p}=0.001$ ). The longest onset of action was observed in the ketamine group, among the ropivacaine groups, the onset of action diminished with an increase in dose and the duration of action significantly extended with an increase in dose (Table 2).

\section{LIGHT MICROSCOPE EXAMINATION}

\section{Medulla Spinalis Sections}

Histopathologic examinations revealed a statistically insignificant change of axonal degeneration in the $\mathrm{R}_{1}$ group, as compared to the other groups $(\mathrm{p}=0.35, \mathrm{n}=4,66 \%)$. This observed axonal degeneration was in the form of a diffuse degeneration in the white matter of the posterior horn of the medulla spinalis, and was more intense around the catheter. Additionally, increased glial cells were observed in the $\mathrm{R}_{0.75}$ group, and bleeding was observed in the ketamine group (Figure 2). 


\begin{tabular}{|c|c|c|c|c|c|c|c|}
\hline \multicolumn{8}{|c|}{ TABLE 2: Effect profiles of groups*. } \\
\hline & Group $R_{0.2}(n=6)$ & Group $R_{0.75}(n=6)$ & Group $R_{1}(n=6)$ & Group K $(n=6)$ & $\mathrm{p}$ & & \\
\hline \multirow[t]{6}{*}{ Time to take effect ( $\mathrm{min}$ ) } & $1.62(1-2.2)$ & $0.75(0.5-1)$ & $0.5(0.3-0.6)$ & $5(4-6)$ & 0.001 & $R_{0.2}-R_{0.75}$ & 0.004 \\
\hline & & & & & & $R_{0.2}-R_{1}$ & 0.004 \\
\hline & & & & & & $R_{0.2}-K_{E}$ & 0.01 \\
\hline & & & & & & $R_{0.75} \cdot R_{1}$ & 0.039 \\
\hline & & & & & & $\mathrm{R}_{0.75} \mathrm{~K}_{\mathrm{E}}$ & 0.007 \\
\hline & & & & & & $R_{1}-K_{E}$ & 0.009 \\
\hline \multirow[t]{6}{*}{ Total duration of action (min) } & $10(8-12)$ & $75(65-90)$ & $85(80-88)$ & $30(25-35)$ & 0.001 & $R_{0.2}-R_{0.75}$ & 0.003 \\
\hline & & & & & & $R_{0.2}-R_{1}$ & 0.003 \\
\hline & & & & & & $\mathrm{R}_{0.2}-\mathrm{K}_{\mathrm{E}}$ & 0.01 \\
\hline & & & & & & $R_{0.75}-R_{1}$ & 0.035 \\
\hline & & & & & & $R_{0.75}-K_{E}$ & 0.008 \\
\hline & & & & & & $R_{1}-K_{E}$ & 0.008 \\
\hline
\end{tabular}

*Median ( min.-max.)

\section{Brain Sections}

Statistical significance was not found when comparing the differences in the frequency of astrogliosis in the brain sections among the groups ( $\mathrm{p}=0.624$, Figure 3 and Table 3 ). However, the differences among the groups with regard neuronal degeneration $(\mathrm{p}<0.0001)$ and reduction in neuron number $(\mathrm{p}=0.043$ ) were found statistically significant. (Figure 3 and Table 3) Further evaluation for neuronal degeneration, the presence of neuronal degeneration in the control group were significantly lower than in the other groups. However, there were no significant differences between the other groups. In addition, only significant differences between ketamine and control groups, $\mathrm{R}_{0.1}$ and control groups were found for reduction in neuron number. The other group differences were not significant

\section{IMMUNOHISTOCHEMICAL EXAMINATION}

No statistical difference was detected using the Kruskal-Wallis test when comparing the immunohistochemical results among the groups, most likely because the number of subjects was too low to detect significance (Table 4).

\section{Medulla Spinalis Sections}

The differences among the groups were not found significant about ventral horn, dorsal horn and white matter of the medulla spinalis (Table 4).

\section{Brain Sections}

No significant differences among the groups were found with regard the hippocampal CA1-CA3 regions, cortex and white matter (Figure 4 and Table $4)$.

\section{DISCUSSION}

In this study, light microscopic analysis revealed that the ketamine group showed significant neuronal degeneration and reduction of neurons in the brain sections. Axonal degeneration was observed $1 \%$ ropivacaine group in the medulla spinalis, but this finding was not reach significance. In the $1 \%$ ropivacaine group, a relative increase in NF intensity was detected using immunohistochemical assessments in the medulla spinalis and in brain sections.

The potential for neurotoxicity of local anesthetics has been suggested in experimental studies showing that histopathologic changes were observed, even though a clinical loss of function was not detected. Ready et al. showed that lidocaine, bupivacaine and tetracaine administered intrathecally in rabbits could be neurotoxic in high concentrations, but neurologic dysfunction did not correlate with these histopathologic changes. ${ }^{16}$ Similarly, Erdine et al. found morphologic evidence of neurotoxicity after intrathecal administration of midazolam, but 


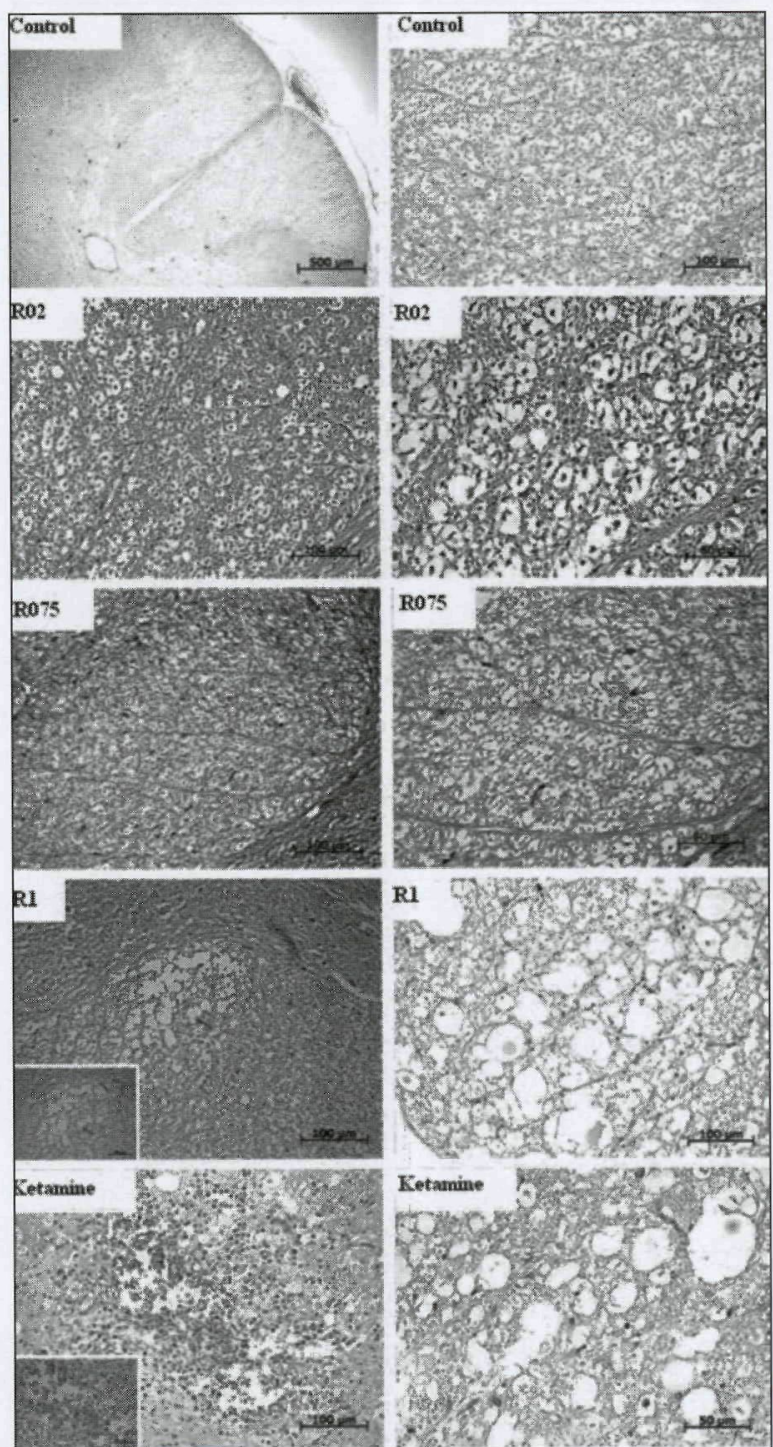

FIGURE 2: Light microscopic appearance of medulla spinalis (axonal degeneration was observed in the R1 group. increased glial cells were observed in the R0.75 group, and bleeding was observed in the Ketamin group) H\&E. (See color figure at http://tipbilimleri.turkiyeklinikleri.com/)

there were no significant findings for the vital parameters or clinical observations. ${ }^{17}$ Therefore, in order to determine the safety limits of intrathecal practices, histological experimental studies are required.

Ropivacaine is a relatively new local anesthetic in comparison with lidocaine, mepivacaine, prilocaine and bupivacaine, and it is thought to have a lower potential for neurotoxicity. Yamashita et al. studied the neurotoxic potential of tetracaine, lidocaine, bupivacaine and ropivacaine applied intrathecally in rabbits. ${ }^{18}$ The authors found vacuoli- zation in the dorsal horn was caused by lidocaine= tetracaine $>$ bupivacaine $>$ ropivacaine, and they noted that lidocaine had the lowest safety border. In their study, vacuolization was seen in only one

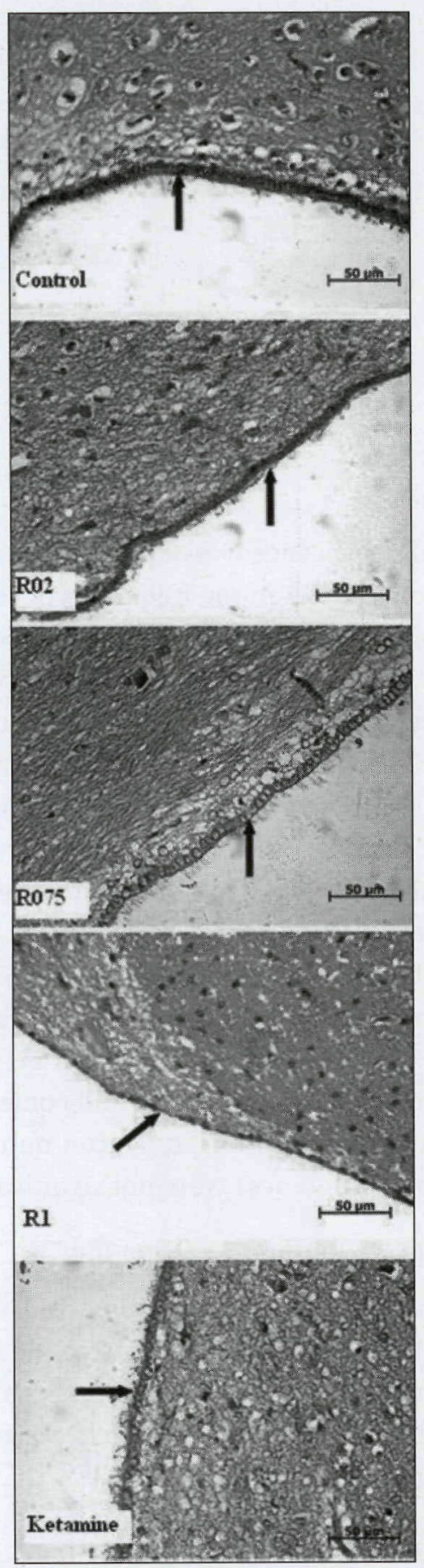

FIGURE 3: Light microscopic evaluation of ependymal thinning (the ependymal thinning observed in the R1 group and neuronal degeneration observed in the ketamine group). H\&E, Scale bar: $50 \mu$.

(See color figure at http://tipbilimleri.turkiyeklinikleri.com/) 


\begin{tabular}{|c|c|c|c|c|c|c|c|c|}
\hline & & & $\begin{array}{c}\text { Group C } \\
(n=6)\end{array}$ & $\begin{array}{c}\text { Group } R_{0.1} \\
(n=6)\end{array}$ & $\begin{array}{l}\text { Group } R_{0.75} \\
(n=6)\end{array}$ & $\begin{array}{l}\text { Group } R_{1} \\
(n=6)\end{array}$ & $\begin{array}{c}\text { Group K } \\
(n=6)\end{array}$ & $p$ \\
\hline \multirow[t]{4}{*}{ Astrogliosis } & \multirow[t]{2}{*}{ Absent } & $n$ & 4 & 3 & 5 & 5 & 5 & \multirow[t]{4}{*}{0.624} \\
\hline & & $\%$ & 66,7 & 50,0 & 83,3 & 83,3 & 83,3 & \\
\hline & \multirow[t]{2}{*}{ Present } & $n$ & 2 & 3 & 1 & 1 & 1 & \\
\hline & & $\%$ & 33,3 & 50,0 & 16,7 & 16,7 & 16,7 & \\
\hline \multirow[t]{4}{*}{ Neuronal degeneration } & \multirow[t]{2}{*}{ Absent } & $n$ & 6 & 0 & 1 & 2 & 0 & \multirow[t]{4}{*}{$<0.0001$} \\
\hline & & $\%$ & 100,0 & , 0 & 16,7 & 33,3 & , 0 & \\
\hline & \multirow[t]{2}{*}{ Present } & $n$ & 0 & 6 & 5 & 4 & 6 & \\
\hline & & $\%$ & 0 & 100,0 & 83,3 & 66,7 & 100,0 & \\
\hline \multirow[t]{4}{*}{ Reduction in neuron number } & \multirow[t]{2}{*}{ Absent } & $n$ & 6 & 2 & 4 & 4 & 2 & \multirow[t]{4}{*}{0.043} \\
\hline & & $\%$ & 100,0 & 33,3 & 66,7 & 66,7 & 33,3 & \\
\hline & \multirow[t]{2}{*}{ Present } & $n$ & 0 & 4 & 2 & 2 & 4 & \\
\hline & & $\%$ &, 0 & 66,7 & 33,3 & 33,3 & 66,7 & \\
\hline
\end{tabular}

subject in the $2 \%$ ropivacaine group, and less than $10 \%$ vacualization was seen in this subject.

In a study by Malinovsky et al., intermittent and continuous infusions of different concentrations of ropivacaine did not induce specific histopathological changes. ${ }^{19}$ Zhong et al. observed histopathologic changes characterized by inflammation, vacuolization and apoptosis, but no behavioral changes in rats treated with ropivacaine during 48 hours, with $90 \mathrm{~min}$. intervals, applied in concentrations of $0.75 \%$ and $1 \% .{ }^{20}$ In repeated applications of ropivacaine, the authors observed neurotoxic changes with an increase of the concentration. Similar to this study, we observed gliosis and axonal degeneration in the medulla spinalis sections of $1 \%$ ropivacaine concentration group. Our results did not reach statistical significance, however, probably owing to the low subject number.

The first experimental studies on ketamine suggested that intrathecal ketamine caused neurotoxic changes. ${ }^{10,11}$ In later studies, it was declared that the preservative substances in the ketamine preparations, especially chlorobutanol, were responsible for the histopathologic changes, and that these neurotoxic changes were not seen when ketamine was used with the preservative benzethonium chloride or without preservatives. ${ }^{9,12}$ In recent years, however, there have been some reports indicating that histopathological changes were observed when preservative-free ketamine was applied intrathecally. In a study by Vranken et al., preservative-free ketamine applied intrathecally in

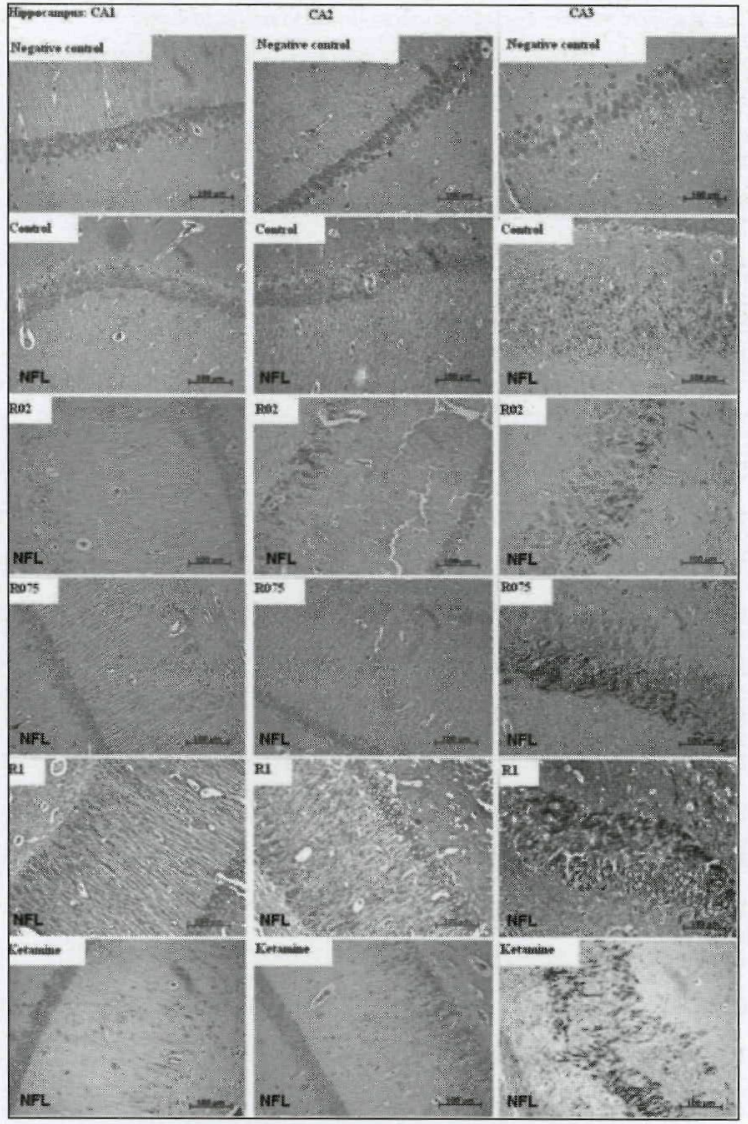

FIGURE 4: Immunohistochemically, neurofilament expression in the hippocampal $\mathrm{CA} 1, \mathrm{CA} 2, \mathrm{CA} 3$ areas (In the R1 group, an increase of NF intensity was observed in the hippocampal regions. The NF intensity in the hippocampal CA1-CA2 regions of the R0.75 group had a similar appearance with the Control group). Scale bar: $100 \mu$. (See color figure at http://tipbilimleri.turkiyeklinikleri.com/)

rabbits for 7 days resulted in no significant changes among motor functions, although axonal swelling and chromatolysis were high, suggesting a toxic damage. ${ }^{21}$ When Gomes et al. applied preservative- 


\begin{tabular}{|c|c|c|c|c|c|c|}
\hline \multicolumn{7}{|c|}{ TABLE 4: Medians of immunocytochemical results*. } \\
\hline Localization & Group C $(n=6)$ & Group $R_{0.1}(n=6)$ & Group $R_{0.75}(n=6)$ & Group $R_{1}(n=6)$ & Group K (n=6) & $p$ \\
\hline Brain CAt & $0.5(0-2)$ & $1(0-2)$ & $0.5(0-3)$ & $2(0-4)$ & $1(0-3)$ & 0.702 \\
\hline Brain CA2 & $1(0-3)$ & $1.5(0-3)$ & $1(0-4)$ & $4(0-4)$ & $1.5(0-4)$ & 0.534 \\
\hline Brain CA3 & $1(0-4)$ & $1.5(0-4)$ & $4(0-4)$ & $2.66(0-4)$ & $1.5(0-4)$ & 0.568 \\
\hline Cortex & $0.5(0-2)$ & $0(0-1)$ & $1.5(0-3)$ & $2(0-4)$ & $1.5(0-4)$ & 0.478 \\
\hline Brain White Matter & $1(0-3)$ & $1(0-3)$ & $3(0-4)$ & $4(0-4)$ & $1.5(0-4)$ & 0.246 \\
\hline \multicolumn{7}{|l|}{ Medulla Spinalis } \\
\hline Gray matter ventral horn & $0(0-1)$ & $0(0-3)$ & $0(0-1)$ & $1(0-3)$ & $0(0-3)$ & 0.639 \\
\hline \multicolumn{7}{|l|}{ Medulla Spinalis } \\
\hline Gray matter dorsal horn & $0(0-2)$ & $0(0-2)$ & $1.5(0-3)$ & $1(0-3)$ & $0(0-3)$ & 0.680 \\
\hline \multicolumn{7}{|l|}{ Medulla Spinalis } \\
\hline White matter & $0(0-2)$ & $0(0-3)$ & $0.5(0-3)$ & $1(0-3)$ & $0(0-3)$ & 0.879 \\
\hline
\end{tabular}

*Median ( min.-max.)

The grading of the immunocytochemical examination was as follows:

$0=$ none; $1=$ rare $(2-3), 2=$ few $(3-10), 3=$ moderate $(10-20)$ and $4=$ serious $(>20$ neurons).

free ketamine intrathecally in dogs, a significant difference in gliosis, axonal edema, chromatolysis and lymphocyte infiltration was observed, as compared to the control groups. ${ }^{22}$

In our study, histopathological analysis of study groups showed neuronal degeneration and reduction in number of neurons significantly in the brain sections, but no increase in neurofilament intensity in immunohistochemical analysis. We cannot disclose the mechanism of these changes. Electron microscopic evaluation would give a more detailed information, but our facilities are not suitable for this assessment. At the same time, it is likely that the difficulty of this type of experimental study, combined with the need for a substantially larger study sample, hinders the ability to establish statistical significance in the evaluation of neurotoxic effects of intrathecal anesthetics.

\section{CONCLUSION}

Our results suggest that the most efficient concentration of ropivacaine is $0.75 \%$, owing to the duration of action and the low evidence of neuronal damage, as determined by histopathological and immunohistochemical assessments. The intrathecal applications of $1 \%$ ropivacaine and ketamine could induce neurotoxic damage, despite a lack of observed functional neurologic deficit.

\section{Acknowledgement}

This study was financed by Abant Izzet Baysal University's Projects Support Fund for Scientific Research. English language in this document has been checked by at least two professional editors, both native speakers of English. For a certificate, please see: $\underline{h t t p: / / w w w . t e x t-}$ check.com/certificate/7YSHv1

\section{REFERENCES}

1. Zink W, Graf BM. The toxicity of local anesthetics: the place of ropivacaine and levobupivacaine. Curr Opin Anaesthesiol 2008;21(5): 645-50.

2. Kazak Z, Mortimer NM, Șekerci S. Spinal anaesthesia with hyperbaric solutions of ropivacaine, levobupivacaine or bupivacaine in major orthopedic surgery. Turkiye Klinikleri J Med Sci 2010;30(2):731-7.
3. Saraç B, Altun A, Yıldııım S, Yıldırım MK, Temiz TK, Bağcivan I, et al. Investigation of the relaxant effect mechanism of ketamine on normal and ovalbumin-Induced trachea in guinea pigs. Turkiye Klinikleri J Med Sci 2011;31(5):1145-52.

4. Hirota K, Lambert DG. Ketamine: its mechanism(s) of action and unusual clinical uses. $\mathrm{Br}$ J Anaesth 1996;77(4):441-4.
5. lida H, Dohi S, Tanahashi T, Watanabe Y, Takenaka M. Spinal conduction block by intrathecal ketamine in dogs. Anesth Analg 1997;85(1):106-10.

6. Dowdy EG, Kaya K, Gocho Y. Some pharmacologic similarities of ketamine, lidocaine, and procaine. Anesth Analg 1973;52(5): 839-42. 
7. Crisp T, Perrotti JM, Smith DL, Stafinsky JL, Smith DJ. The local monoaminergic dependency of spinal ketamine. Eur J Pharmacol 1991;194(2-3):167-72.

8. Annetta MG, lemma D, Garisto C, Tafani C, Proietti R. Ketamine: new indications for an old drug. Curr Drug Targets 2005;6(7):78994.

9. Borgbjerg FM, Svensson BA, Frigast C, Gordh $T \mathrm{Jr}$. Histopathology after repeated intrathecal injections of preservative-free ketamine in the rabbit: a light and electron microscopic examination. Anesth Analg 1994;79(1):105-11.

10. Brock-Utne JG, Kallichurum S, Mankowitz E, Maharaj RJ, Downing JW. Intrathecal ketamine with preservative - histological effects on spinal nerve roots of baboons. S Afr Med J 1982;61(12):440-1.

11. Malinovsky JM, Cozian A, Lepage JY, Mussini JM, Pinaud M, Souron R. Ketamine and midazolam neurotoxicity in the rabbit. Anesthesiology 1991;75(1):91-7.

12. Malinovsky JM, Lepage JY, Cozian A, Mussini JM, Pinaudt M, Souron R. Is ketamine or its preservative responsible for neurotoxicity in the rabbit? Anesthesiology 1993;78(1):10915.

13. Mink RB, Johnston JA. Changes in brain neurofilament and beta-tubulin proteins after cerebral hypoxia-ischemia in rabbits. Pathobiology 2000;68(1):43-52.

14. Gotow T. Neurofilaments in health and disease. Med Electron Microsc 2000;33(4):173-99.

15. Langerman L, Chaimsky G, Golomb E, Tverskoy M, Kook Al, Benita S. A rabbit model for evaluation of spinal anesthesia: chronic cannulation of the subarachnoid space. Anesth Analg 1990;71(5):529-35.

16. Ready LB, Plumer MH, Haschke RH, Austin E, Sumi SM. Neurotoxicity of intrathecal local anesthetics in rabbits. Anesthesiology 1985; 63(4):364-70.

17. Erdine S, Yücel A, Ozyalçin S, Ozyuvaci E, Talu GK, Ahiskali B, et al. Neurotoxicity of midazolam in the rabbit. Pain 1999;80(1-2):41923.

18. Yamashita A, Matsumoto M, Matsumoto $S$, Itoh M, Kawai K, Sakabe T. A comparison of the neurotoxic effects on the spinal cord of tetracaine, lidocaine, bupivacaine, and ropivacaine administered intrathecally in rabbits. Anesth Analg 2003;97(2):512-9, table of contents.

19. Malinovsky JM, Charles F, Baudrimont $M$, Péréon $Y$, Le Corre $P$, Pinaud $M$, et al. Intrathecal ropivacaine in rabbits: pharmacodynamic and neurotoxicologic study. Anesthesiology 2002;97(2):429-35.

20. Zhong Z, Qulian G, Yuan Z, Wangyuan Z, Zhihua $S$. Repeated intrathecal administration of ropivacaine causes neurotoxicity in rats. Anaesth Intensive Care 2009;37(6):929-36.

21. Vranken JH, Troost $D$, de Haan $P$, Pennings $F A$, van der Vegt MH, Dijkgraaf MG, et al. Severe toxic damage to the rabbit spinal cord after intrathecal administration of preservativefree S(+)-ketamine. Anesthesiology 2006;105 (4):813-8.

22. Gomes LM, Garcia JB, Ribamar JS Jr, Nascimento AG. Neurotoxicity of subarachnoid preservative-free $\mathrm{S}(+)$-ketamine in dogs. Pain Physician 2011;14(1):83-90. 
Copyright of Turkiye Klinikleri Journal of Medical Sciences is the property of Ortadogh Reklam Tanitim ve Yayincilik Turizm Egitim Insaat Sanayi ve Ticaret A.S. and its content may not be copied or emailed to multiple sites or posted to a listserv without the copyright holder's express written permission. However, users may print, download, or email articles for individual use. 